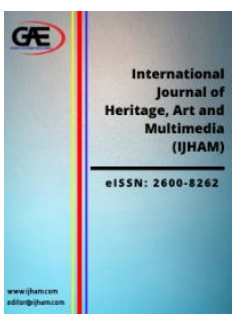

\author{
INTERNATIONAL JOURNAL OF \\ HERITAGE, ART AND MULTIMEDIA \\ (IJHAM) \\ wWw.ijham.com
}

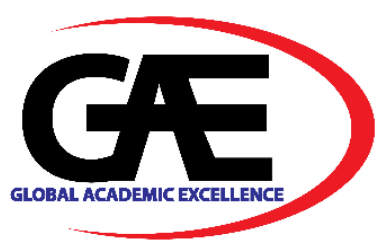

\title{
THE ARTS AND HISTORICAL REMAINS IN THE CAVE TEMPLES IN IPOH, MALAYSIA
}

Tan Ai Boay ${ }^{1 *}$

1 Universiti Tunku Abdul Rahman

Email: tanab@utar.edu.my

* Corresponding Author

\section{Article Info:}

Article history:

Received date: 18.10 .2021

Revised date: 01.11. 2021

Accepted date: 07.11.2021

Published date: 01.12.2021

To cite this document:

Tan, A. B. (2021). The Arts And Historical Remains In The Cave Temples In Ipoh, Malaysia. International Journal of Heritage, Art and Multimedia, 4 (15), 14-32.

DOI: $10.35631 /$ IJHAM.415002.

This work is licensed under CC BY 4.0

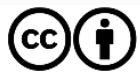

\begin{abstract}
:
The purpose of this paper is to demonstrate the arts and historical remains in the cave temples of Ipoh, Perak, Malaysia. Ipoh is well known for its numerous limestone cave temples. Based on the fieldwork survey from 2016 to 2020, Ipoh has 50 cave temples. Before the survey, the number of cave temples in Ipoh was unknown. These cave temples can be divided into three types based on their physical appearances. The paper discusses the arts and historical remains kept in selected cave temples that were established before World War II. The arts discussed in this paper can be divided into visual and literary arts, such as mural, drawing, statue and poetry. The majority of the historical remains taken are archival and epigraphical materials. The epigraphical materials are carved in bronze bells, wooden tablets, brass censers, stone inscriptions, and other materials. This paper aims to highlight the diversity of the arts and historical remains in Nusantara.
\end{abstract}

Keywords:

Arts, Historical Remains, Cave Temple, Ipoh

\section{Introduction}

Ipoh, the capital of Perak, is also known as the city of hills because it is surrounded by hills, especially limestone hills. In pre-history, aboriginal people lived in these limestone caves. After the mid- $19^{\text {th }}$ century, these caves were occupied by the migration community, mainly the Chinese. A large number of Chinese migrated to Kinta Valley in search of mining opportunities. By the late $19^{\text {th }}$ century, the Chinese had established themselves as the most dominant community in Kinta. Similar to the Chinese in other parts of Malaya, the Chinese in Kinta brought their beliefs with them and then built temples in their new lands. Unlike their 
Volume 4 Issue 15 (December 2021) PP. 14-32

DOI 10.35631/IJHAM.415002

counterparts elsewhere, the Chinese in Ipoh were able to build a temple within the limestone cave.

How many cave temples are there in Ipoh? The investigation was initiated by Dato Dr Mah Han Soon, the former chairman of the Perak Non-Islamic Affairs Department. The research team ${ }^{\mathrm{i}}$ worked hard to discover these temples, which could be hidden in a remote area surrounded by dozens of ferocious dogs. The research team attempts to unravel the arts and historical mysteries of these temples not only by searching the materials in situ, including dark and dusty storerooms but also by accessing old photos and archival materials in Malaysia's National Archives.

The output of the research project is a book - Trials of The Nanyang Chinese: History and Legends of the Cave Temples in Ipoh of Malaysia (Tan \& Toh, 2017). The book only listed the names of 49 cave temples that were discovered. Only seven temples kept the evidence that was established before World War II were detailed in the book. Years later, new historical materials were discovered. In early 2020, we visited an abandoned Chinese cave temple, under the guidance of Chaw Yeh Saw, an archaeologist department postgraduate student at University Science Malaysia.

The paper has two aims: first, it records the cave temples discovered in Ipoh from 2016 to 2020; second, it explores the arts and primary historical evidence, mainly drawing, mural, statue, poem and epigraphical materials in these cave temples. The research also attempts to answer the question: what is the inheritance and localisation of these arts which originated from China but have been localised in Malaysia?

\section{Literature Review}

From the perspective of Chinese epigraphical research, this should be deemed as relevant, as should the study of Wolfgang Franke and Chen Tieh Fan, with their three-volume book Chinese Epigraphic Materials in Malaysia. (Wolfgang \& Chen 1982, 1985 and 1987). In 1969, Professor Jao Tsung-I (饒宗頤) was the first college scholar to attempt a comprehensive listing of all Chinese inscriptions in Singapore and West Malaysia with his publication "A Chronology Survey on Chinese Inscription in Singapore and Malaysia” (〈星馬華文碑刻繋年〉) (Wolfgang and Chen 1982: 4). Takeo Hibino(日比野丈夫), Chen Ching Ho (陳荊和), Tan Yoke Seong(陳育嵩), Chen Tieh Fan (陳鐵凡) and Chan Cheung (陳璋) contributed to the collection of Chinese epigraphic materials in Singapore and West Malaya, before Wolfgang Franke and Chen Tieh Fan. In the $21^{\text {st }}$ century, epigraphic materials from both temples (Lew Boon Hooi \& Chong Kok Ming 2016; Tan 2019) and cemeteries (Wong Wun Bin 2013; Foo Yew Chew 2016; Danny Wong Tze Ken 2016; Tan Ai Boay 2017,) captured the concern from college-trained scholars.

While Wolfgang and Chien's collection extended throughout Malaysia, their search for artefacts in the state of Perak was very limited. Many epigraphic materials in Perak had escaped their attentions, and of those that were discovered as the result of their exhaustive list of every artefact discovered, analytical studies remained unfinished. For instance, the book only collected three-temple epigraphical materials in the Kinta district. At least 22 temples in Kinta that housed hundred-year-old epigraphical materials were not recorded in the book. This left 
Volume 4 Issue 15 (December 2021) PP. 14-32 DOI 10.35631/IJHAM.415002

opportunities for a myriad of research to be undertaken and to move forward from where they left off.

Since then, only two un-unpublished conference papers have discussed the arts in these cave temples. Toh Teong Chuan's paper - "A Taoist priest awakening poem in Nam Thean Tong, Ipoh". (Toh Teong Chuan 2017). The paper has used the unveil mural poem. The poem mural was discovered halfway up a hill in the dark and humid shrine hall. The mural's colours have faded, and the writing has become illegible. Toh Teong Chuan's paper analyses the 39 awakening poems. Ling Liong Ngo contributed another paper on the study of poem descriptions of Perak Tong, a famous Buddhist cave temple. She presented a conference paper titled "The Study of a classical poetry in Cave Temple in Malaysia - The discussion of Perak Tong Eight Views Poetry Anthology" (Ling Liong Ngo 2017). The poems are the focus of the two papers. Even though, the paper mainly reviews the findings of Toh Teong Chuan's paper because the poems take the form of calligraphy arts written on the temple walls.

\section{The Survey Of The Cave Temples In Ipoh}

The State of Perak became the first Malay State to be intervened by the British in 1874. The state is divided into eight districts: Larut and Matang, Kinta, Kuala Kangsar, Lower Perak, Krian, Batang Padang, Selama and Upper Perak. The development of the tin industry in Perak had resulted in an influx of Chinese migrants. Malaya became the largest tin exporting country in the 1880s and Perak contributed half of the exports. As such, in 1889, the Chinese became Perak's largest population with $85 \%$ of them residing in the Kinta and Larut districts (Perak Government Gazette 1889, p. 220). As shown in Graph 1, the Chinese population in Kinta has grown rapidly since then.

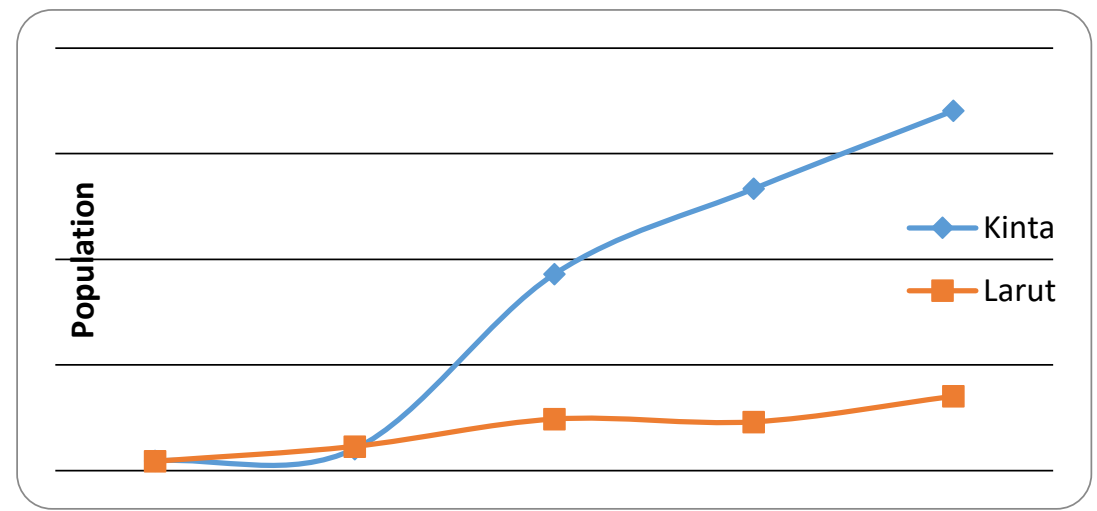

Graph 1: Chinese Population In Kinta And Larut (1879, 1889, 1901, 1911 and 1931)

Source: (Perak Government 1889, p. 220; Hare 1902, p. 32; Pountney 1911, p. 94; Vlieland 1932, pp. 122-123.)

Kinta's growing Chinese population has resulted in the establishment of Chinese temples. The earliest evidence of these temples was discovered during these rapid growth periods, including the cave temple. 
Volume 4 Issue 15 (December 2021) PP. 14-32 DOI 10.35631/IJHAM.415002

In the paper, the "Cave Temple" was divided into four categories based on their physical appearances:

A. Cave temple: The entire or part of the temple is located within the cave.

B. Temple in the cave's vicinity: The temple is located within the cave's surrounding areas.

C. Abandoned cave temple: The temple has been abandoned and no devotees have visited it.

\section{Type A: Cave Temple}

The entire or a part of these cave temples located continue to serve as places of religious worship. The research uncovered 39 Cave temples (Table 1) in Ipoh. Among these cave temples, Kwong Fook Ngam(廣福岩), the Buddhist temple may be the oldest, followed by Nam Tou Ngam (南道岩), the Taoism temple. Seven cave temples contain historical evidence that they were built up before World War II. Kwong Fook Ngam (廣福岩), Sam Poh Tong (三 寶洞) and Perak Tong(霹靂洞) are Buddhist temples, whereas Nam Tou Ngam(南道岩), Nam Thean Tong(南天洞) and Loong Thow Ngam (龍頭岩) belonged to Taoism. The Tung Wah Tong (東華洞) which was initiated by Leong Sin Nam (梁榮南, 1880-1940), the famous Chinese leader was difficult to categorise to any single religion.

\begin{tabular}{|c|c|c|c|}
\hline \multirow{2}{*}{ No. } & \multicolumn{2}{|c|}{ Temple } & \multirow{2}{*}{ Main Deity } \\
\hline & Chinese & $\begin{array}{l}\text { Registered name in } \\
\text { Malay or English }\end{array}$ & \\
\hline 1 & 巴占法天宫仙洞 & Tokong Wuat Tian Keong & Fa Zhu Gong(法主公) \\
\hline 2 & $\begin{array}{c}\text { 巴占大众花园山边观音 } \\
\text { 信徒会 }\end{array}$ & $\begin{array}{l}\text { Persatuan Penganut Agama } \\
\text { Tao Guan Yin Tokong Cina }\end{array}$ & Guan Yin \\
\hline 3 & 白云寺 & - & Shakyamuni Buddha \\
\hline 4 & 般若岩 & - & Shakyamuni Buddha \\
\hline 5 & 慈云山 & - & Guan Yin \\
\hline 6 & 大乘岩佛寺 & Tokong Da Seng Ngan & Shakyamuni Buddha \\
\hline 7 & $\begin{array}{c}\text { 打扪创意古藏传禅修中 } \\
\text { 心 ( 前南龙古庙 ) }\end{array}$ & $\begin{array}{c}\text { Thrangu Dharma Retreat } \\
\text { Centre }\end{array}$ & Maitreya Bodhisattva \\
\hline
\end{tabular}


Volume 4 Issue 15 (December 2021) PP. 14-32

DOI 10.35631/IJHAM.415002

\begin{tabular}{|c|c|c|c|}
\hline \multirow{2}{*}{ No. } & \multicolumn{2}{|c|}{ Temple } & \multirow{2}{*}{ Main Deity } \\
\hline & Chinese & $\begin{array}{l}\text { Registered name in } \\
\text { Malay or English }\end{array}$ & \\
\hline 8 & 德隆祈达维峇沙那暹庙 & $\begin{array}{c}\text { Wat Thumcitta Vipassana } \\
\text { Temple }\end{array}$ & Shakyamuni Buddha \\
\hline 9 & 敦珠新岩藏佛教中心 & $\begin{array}{c}\text { Dudjom New Treasure } \\
\text { Buddhist Society }\end{array}$ & Padmasambhava \\
\hline 10 & 东华洞 & Tung Wah Tong & The Jade Emperor \\
\hline 11 & 法喜寺 & $\begin{array}{c}\text { Dhamma Piti Meditation } \\
\text { Monastery }\end{array}$ & Shakyamuni Buddha \\
\hline 12 & 福昌宮 & - & $\begin{array}{c}\text { The Supreme Elderly } \\
\text { Lord(太上老君) }\end{array}$ \\
\hline 13 & 福佈洞 & $\begin{array}{c}\text { Wat PhupaRattanawarararm/ } \\
\text { FookPu Tong/ Cave of } \\
\text { Happiness }\end{array}$ & Shakyamuni Buddha \\
\hline 14 & 观音洞 & Kwan Yin Cave Temple & Shakyamuni Buddha \\
\hline 15 & 观音坛八仙洞 & $\begin{array}{c}\text { Goddess of Mercy and Eight } \\
\text { Immortals Cave }\end{array}$ & Guan Yin \\
\hline 16 & 观音紫明庵 & Kuan Yin Chee MengAam & Guan Yin \\
\hline 17 & 光炽岩 & $\begin{array}{c}\text { Persatuan Penganut Dharma } \\
\text { Kong Chee Nguam }\end{array}$ & Shakyamuni Buddha \\
\hline 18 & 广福岩 & $\begin{array}{c}\text { Kwong Fook Ngam / Kwong } \\
\text { Fuk Ngam }\end{array}$ & Shakyamuni Buddha \\
\hline 19 & 极乐洞 & Kek Look Tong & Hua-Yen Trinity \\
\hline 20 & 乐苑寺 & $\begin{array}{l}\text { Pertubuhan Meditasi } \\
\text { Sukhavana/Sukhavana } \\
\text { Meditation Monastery }\end{array}$ & Shakyamuni Buddha \\
\hline
\end{tabular}


Volume 4 Issue 15 (December 2021) PP. 14-32

DOI 10.35631/IJHAM.415002

\begin{tabular}{|c|c|c|c|}
\hline \multirow{2}{*}{ No. } & \multicolumn{2}{|c|}{ Temple } & \multirow{2}{*}{ Main Deity } \\
\hline & Chinese & $\begin{array}{l}\text { Registered name in } \\
\text { Malay or English }\end{array}$ & \\
\hline 21 & 莲花宫 & - & Zhang Tian Shi(张天师) \\
\hline 22 & 灵山妙圆禅寺 & $\begin{array}{l}\text { Pertubuhan Pertapaan Penganut } \\
\text { Agama Buddha Meow Yuen }\end{array}$ & Shakyamuni Buddha \\
\hline 23 & 灵仙岩 & Ling Sen Tong & Guan Yin \\
\hline 24 & 龙头岩 & $\begin{array}{c}\text { Loong Thow Ngam / Lung } \\
\text { Thau Ngam }\end{array}$ & Guan Di \\
\hline 25 & 玅缘禅林 & - & Shakyamuni Buddha \\
\hline 26 & 明心殿 & $\begin{array}{c}\text { Persatuan Penganut Ming Xin } \\
\text { Dian Tebing Tinggi }\end{array}$ & $\begin{array}{c}\text { Supreme of Bao Zheng(包 } \\
\text { 拯大人) }\end{array}$ \\
\hline 27 & 南道岩 & Nam Tou Ngam & The Supreme Elderly Lord \\
\hline 28 & 南天洞 & Nam Thean Tong & The Supreme Elderly Lord \\
\hline 29 & 霹雱洞 & Perak Tong & Shakyamuni Buddha \\
\hline 30 & 三宝洞 & Sam Poh Tong & Shakyamuni Buddha \\
\hline 31 & 三教院观音庙 & - & Guan Yin \\
\hline 32 & 森山佛脚庙 & Wat Putabatwanapup & Shakyamuni Buddha \\
\hline 33 & 四面佛洞 & $\begin{array}{c}\text { Persatuan Penganut Erawan } \\
\text { Shrine }\end{array}$ & Erawan \\
\hline 34 & 送子观世音 & $\begin{array}{l}\text { Pertubuhan Penganut Dewi } \\
\text { Song Zi Guan Shi Yin }\end{array}$ & Nan Hai Guan Yin \\
\hline 35 & 无极岩 & $\begin{array}{c}\text { Persatuan Penganut Moo } \\
\text { KekNgam Ipoh }\end{array}$ & Guan Yin \\
\hline 36 & 修持金刚精舍 & $\begin{array}{l}\text { Persatuan Penganut Dewa } \\
\text { Jingang Jing She }\end{array}$ & Padmasambhava \\
\hline
\end{tabular}


Volume 4 Issue 15 (December 2021) PP. 14-32

DOI 10.35631/IJHAM.415002

\begin{tabular}{|c|c|c|c|}
\hline \multirow{2}{*}{ No. } & \multicolumn{2}{|c|}{ Temple } & \multirow{2}{*}{ Main Deity } \\
\cline { 2 - 4 } & Chinese & $\begin{array}{l}\text { Registered name in } \\
\text { Malay or English }\end{array}$ & \multirow{2}{*}{ Li Bai (李太白师尊) } \\
\hline 37 & 云仙洞德教会紫霄阁 & $\begin{array}{r}\text { Persatuan Memperbaiki Akhlak } \\
\text { Hoon Sean Tong,Che Seow } \\
\text { Kor }\end{array}$ & - \\
\hline 38 & 真佛宗怡保雷藏寺 & Do Not know \\
\hline 39 & 紫竹六佛祖坛 & Chee Chak Loke Fuat Chow & Guan Yin \\
\hline
\end{tabular}

\section{Table 1: Cave Temples in Ipoh}

\section{Types B: Temple In The Cave's Vicinity}

This type of temple is located within the cave, nearby areas, or within 100 metres of the cave. Believers continue to visit these temples for religious purposes. Some of these temples appear to be built into the cave, but they are not. There are 10 temples attributed to this type (Table 2).

\begin{tabular}{|c|c|c|c|}
\hline \multirow{2}{*}{ No. } & \multicolumn{2}{|c|}{ Temples } & \multirow{2}{*}{ Main Deity } \\
\hline & Chinese & Malay / English & \\
\hline 1 & 布塔尼密坛暹庙 & Wat Puthanimittam & Shakyamuni Buddha \\
\hline 2 & 打扪八仙坛 & - & The Eight Immortals \\
\hline 3 & 拉蒙耶旺萨伟伽耶塔 & $\begin{array}{c}\text { Reamonnya Wongsa Wijaya } \\
\text { Pagoda }\end{array}$ & Shakyamuni Buddha \\
\hline 4 & 灵霄殿 & Ling Xiao Dian & The Eight Immortals \\
\hline 5 & 蒙坤三宝庙 & - & Shakyamuni Buddha \\
\hline 6 & 弥陀道场 & $\begin{array}{c}\text { Pertubuhan Penganut Buddha } \\
\text { Pureland Amitabha }\end{array}$ & Amitabha \\
\hline 7 & 盘古庙 & $\begin{array}{l}\text { Persatuan Penganut Agama } \\
\text { Tao Poon Koo Khoong }\end{array}$ & Pangu (盘古) \\
\hline 8 & 太上老君庙 & $\begin{array}{l}\text { Persatuan Penganut Dewa Tai } \\
\text { Shang Lao Jun Ipoh,Perak }\end{array}$ & $\begin{array}{l}\text { The Supreme Elderly } \\
\text { Lord }\end{array}$ \\
\hline 9 & 心意佛院 & $\begin{array}{l}\text { Persatuan Enlightened Heart } \\
\text { Buddhist / Enlightened Heart } \\
\text { Tibetan Buddhist Temple }\end{array}$ & Shakyamuni Buddha \\
\hline 10 & 玉仙宮 & - & Shakyamuni Buddha \\
\hline
\end{tabular}

Table 2: Temple In The Cave's Vicinity 
Volume 4 Issue 15 (December 2021) PP. 14-32 DOI 10.35631/IJHAM.415002

By compiling Table 1 and Table 2, one can find that $40 \%$ of these cave temples enshrine Shakyamuni Buddha at the main shrine hall, followed by Guan Yin (觀音) (16\%). Chinese traditional religions, which include Buddhism, Taoism and folk religion, are very complex. Usually, the temple's main hall, which houses Shakyamuni Buddha and Amitabha, should be classified as Buddhism. Shakyamuni Buddha is the founder of the Buddhist religion. Amitābha, known as "The Buddha of Immeasurable Light and Life", is the principal buddha in Pure Land Buddhism in the Mahayana Buddhism. Taoism considers Laozi (老子) to be the religion's founder. In other words, the deification process transformed Laozi into The Supreme Elderly Lord. Hence, the temple that houses The Supreme Elderly Lord in the main shrine hall is usually classified as a Taoist temple.

The "Chinese Traditional Religion" is a mixture of Buddhism, Taoism and folk religion. According to the census in Malaya during the colonial period, the British official mentioned that it was difficult to classify the Chinese religion. The category of Chinese religion can be changed, such as "Confucian", "Other", and "Chinese Traditional Religion" (Tan Ai Boay, 2015). The cave temples may reflect Chinese traditional religious practises, such as worshipping Buddha, Boddhisatva, deities and ancestors. Even though the "purification religion movement", especially Buddhism, began after independence, the majority of Chinese practising "Chinese traditional religion" until today. Hence, the research does not intend to classify the religious attribution to every temple mentioned above. It may be complex, and the temple's "self-identity" is changeable. For instance, the Tung Wah Tong, which was established in 1926, enshrines the Jade Emperor as its main deity. In 1980, Tung Wah Tong was officially registered as "Pusat Meditasi Buddhist Tung Wah" (Tung Wah Buddhist Meditation Centre). Nowadays, the temple committee considers Tung Wah Tong to be a Taoist temple and has joined the Taoist Association Malaysia.

The above-mentioned temple is still visited by tourists and devotees. The cave temple of type $\mathrm{C}$ is another story.

\section{Type C: Abandoned Cave Temple}

The temple was abandoned and only a few explorers and archaeologists had visited it. There is only one abandoned cave temple that was discovered.

The abandoned temple is located at Kampung Kapayang with a broken stair and arched door. The graffiti Chinee calligraphy arts on the stone demonstrate that it was named Yun Tian Yan (雲天岩) (Picture 1), or Yuan Tian Xian Dong (雲天仙洞). 


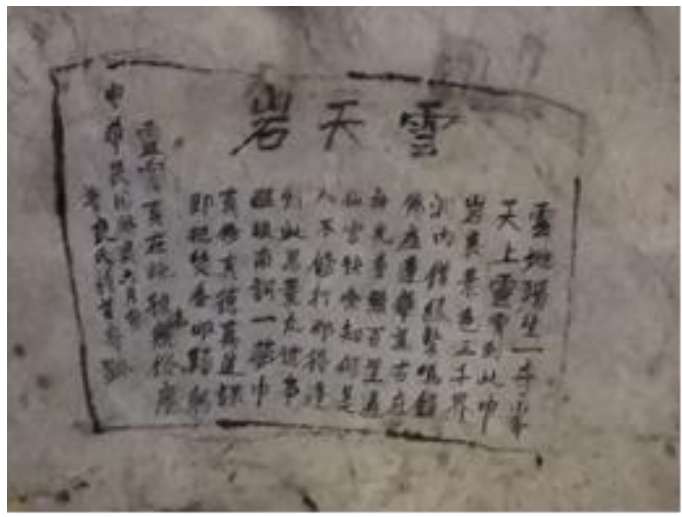

DOI 10.35631/IJHAM.415002

\section{Picture 1: The Name Of The Temple -- Yun Tian Yan (雲天岩)}

When the Society Enactment was implemented at Perak in 1895, the temple was registered as “Wan Sin Tung”(雲仙洞) by Kung Sin Tak (Federated Malay State Government Gazette 1895). The earliest graffito in situ dates from 1904: "This place is towering mountains and precipitous ridges, flourish jungle and prune bamboo." This sentence was quoted from "Preface to the Collection of Poems Composed at the Orchid Pavilion” (Lanting Xu, 蘭亭集序), written by Wang Xizhi (王羲之 303-361), a famous Chinese calligrapher.

The cave had been inhabited by Orang Asli (aboriginal people) during the pre-history period. They left a prehistory mural behind. The temple was occupied by the Chinese at the end of the $19^{\text {th }}$. According to the mottled poem on the stone, the temple enshrined Buddha and resided by monks in the 1920s.

The period and the reason for the temple's abandonment are still unknown.

\section{The Visual And Literature Arts In These Cave Temples}

Arts is an application and expression of human creative skill and imagination. Usually, arts are divided into visual arts, literary arts and performing arts. The arts found in these cave temples are drawing and painting, sculpture or statue and poem. These visual and literary arts are mainly found in Nam Thean Tong, a Taoist cave temple.

\section{Painting}

Painting is the first type of visual arts performance in the temple. The paintings found in Nam Thean Tung can be classified into two types:

\section{The Pictures Of The Deities}

There are 329 deities names recognised in the Nam Thean Tong. ${ }^{1}$ The majority of the deities' names were written on a wood tablet, but some were drawn on wooden materials.

\footnotetext{
${ }^{1}$ This part mainly refers to Liow Min Wei (2017). 


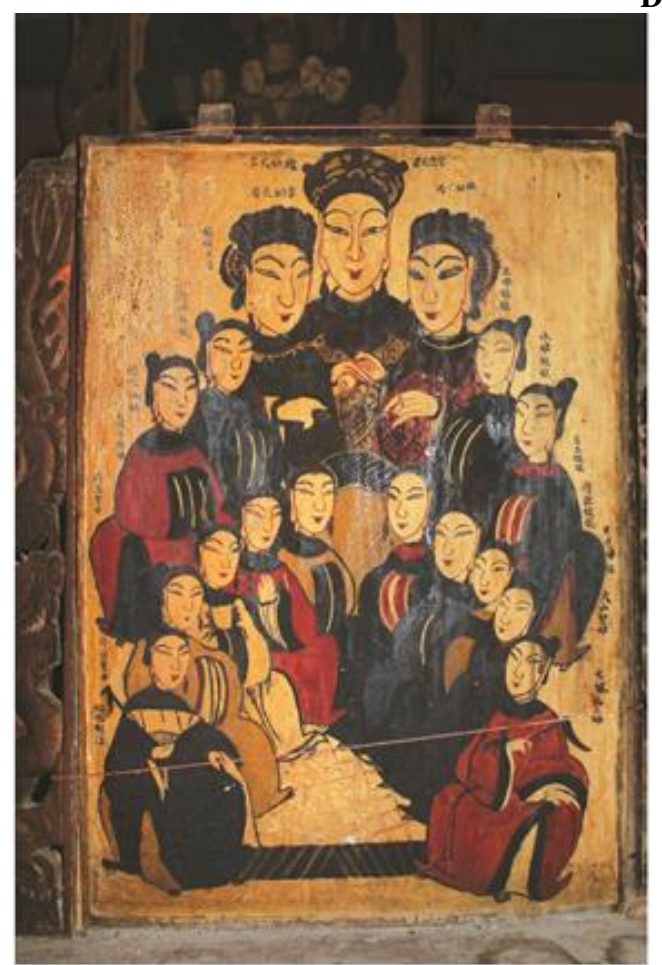

DOI 10.35631/IJHAM.415002

\section{Picture 2: Goddess Picture In Nam Thean Tong}

Picture 2 is one of the deity paintings that were discovered in Nam Thean Tong. The picture depicts 17 goddesses with their names or titles. Even though this is a Taoist cave temple, the deity seen in this picture is "Mu Lian (目連)" (Maudgalyāyana or Mahāmaudgalyāyana). Maudgalyāyana and Śāriputra are considered as Buddha's two foremost male disciples. Maudgalyāyana is well known for his filial piety, which he demonstrated by visiting the hell and transferring his merits to his mother. One of the fundamental principles of the Chinese Hungry Ghost Festival is to dedicate the merits to ancestors during the festival. A famous Buddha male disciple is depicted as a goddess in the old Taoist temple. Another goddess in this painting comprises protection embryo goddess, land-lord goddess. This goddess in this picture may be associated with motherhood and protection.

Nam Thean Tong has six frames of deities' pictures, with gods and goodness occupying half of each. The three goddess pictures contain 35 deities, but some of their titles or names are unknown. The three gods' picture should be the “Ten Temples Yama” (十殿閻羅). ${ }^{2}$ Yama is the death deity in Hindu and Buddhist beliefs. The Chinese society has absorbed the concept and "sinicized" Yama. According to Chinese legends and belifs, the ten Yama played various roles and punished the decease based on their various types of karmas.

Who is the artist? Did the artist draw the figures in the Cave temple, or was it brought from China? I believe the artist is a Taoist priest in the cave temple. He not only drew the deities but also painted the mural and wrote the poem. His identity will be discussed in the following paragraph.

\footnotetext{
${ }^{2}$ Two of the deity names cannot be recognised. 


\section{The Mural}

DOI 10.35631/IJHAM.415002

Mural research is one of the most difficult aspects of the study of this cave temple. Every painting demonstrates "The seven-character quatrain" poem. There might be 14 story paints on the wooden material. Unfortunately, the colour of the painting and writing has faded. One of the stories that can be recognised is the fiction of Fan Lihua (樊梨花) and her husband Xue Dingshan (薛丁山) (Picture 3)

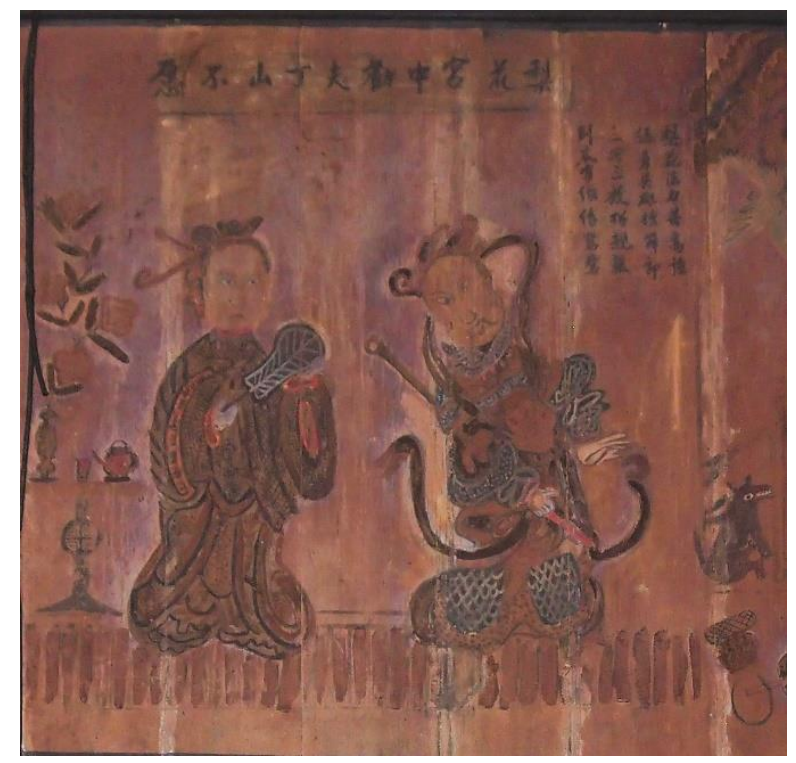

Picture 3: The Mural In Nam Thean Tong

The fiction and Fan Lihua and Xue Dingshan occurred during the early years of Dynasty Tang. Fan Lihua, a female general from Western Liang, falls in love with Xue Dingshan, a general of Dynasty Tang. Fan Lihua, a heroine with superpowers, caught Xue Dingshan three times before releasing him. Finally, they fell in love with each other and married.

The mural depicts the superpowers of the god or goddess. However, the mural is hard to understand without the poem description. The Taoist priest in the cave intended to pass on his artistic abilities and religious perception to the next generation.

\section{The Statue}

The old, mystery Nam Thean Tong has a lot of deity statues. The colour and model of the statue revealed that different period artefacts are kept in this cave temple. The antique artefacts should be the Hakka style deity statue (Picture 4). This style of sculpture is unusual in Malaysia. The deity held the seal that carved the title or name. 


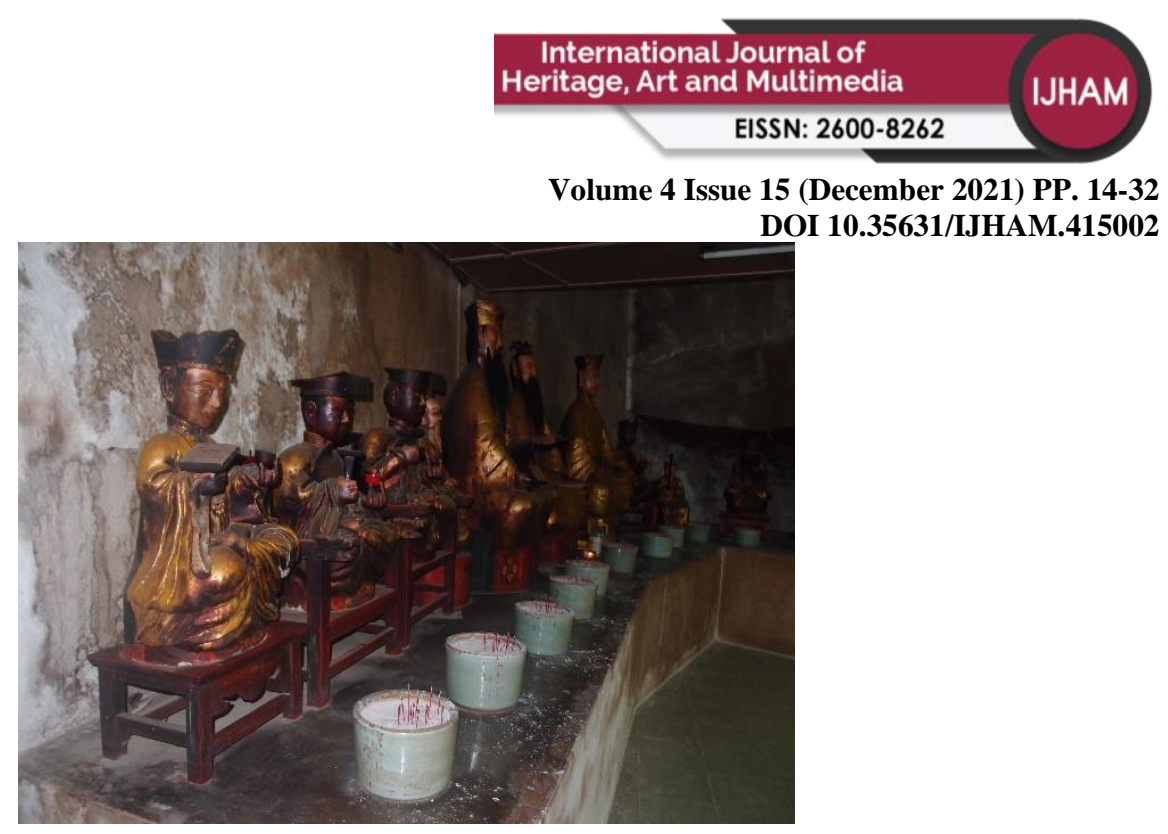

Picture 4: The Hakka Style Deities Statues

Usually, the title or name of the deities is engraved in the seal. Even the character of the seal can be read, and who is the deity may be an unsolved problem. For example, the seal read "Lao Zu Dao Jun (老祖道君) (Picture 5). Is Lao Zu Dao Jun another title for Laozi or Supreme Elderly Lord (Tai Shang Lao Jun, 太上老君) one of the Three Pure Ones, the highest divinities of Taoism? Usually, the Supreme Elderly Lord holds horsetail whisk, or tablet or "Moon" or "Sun". The stature of Picture 5 holds the sword. This may also be the Hongjun Laozu (鴻鈞老 祖). However, on the upper level of the hall, there is another hall named "Hongjun Hall" (鴻 鈞殿) (picture 6). I have never seen two identical halls designed to enshrine one deity in a temple.

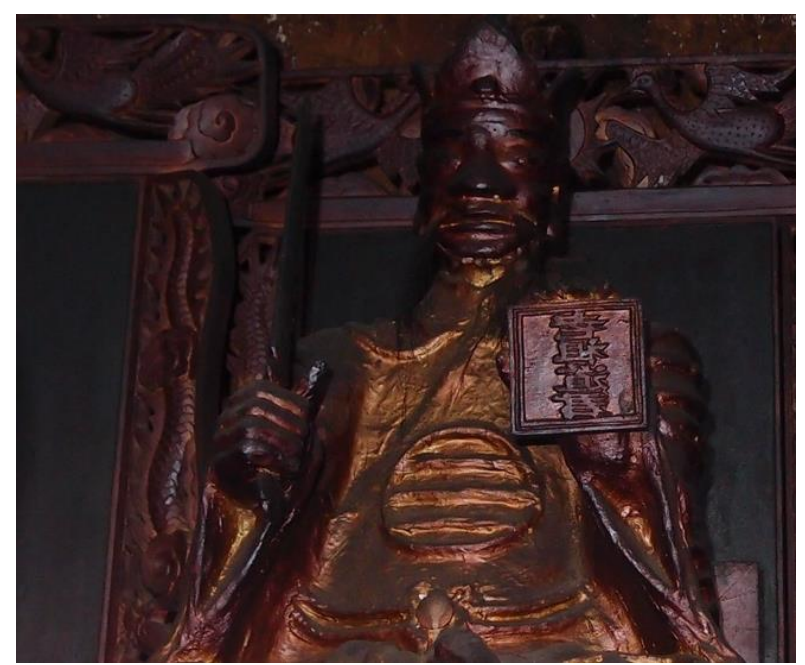

\section{Picture 5: The Deity Holds A Seal Of "Lao Zu Dao Jun"}

According to the style of the Hongjun Statue in Hongjun Hall, this is a comparatively new statute. The original statute of Hongjun may have disappeared or been displaced. The research speculates that the stature in Picture 5 was originally put in the Hongjun Hall. The reason for the misplacement might have occurred during the renovation following the establishment of the committee in the 1970s. 
Volume 4 Issue 15 (December 2021) PP. 14-32 DOI 10.35631/IJHAM.415002

Under the dark staircase toward the mountain, the research team found a bizarre statue (Picture 6 ). The stature has five heads. The head resembles that of a human, with eyebrows, eyes and nose, but the human mouth is replaced by a beak. What exactly is the deity?

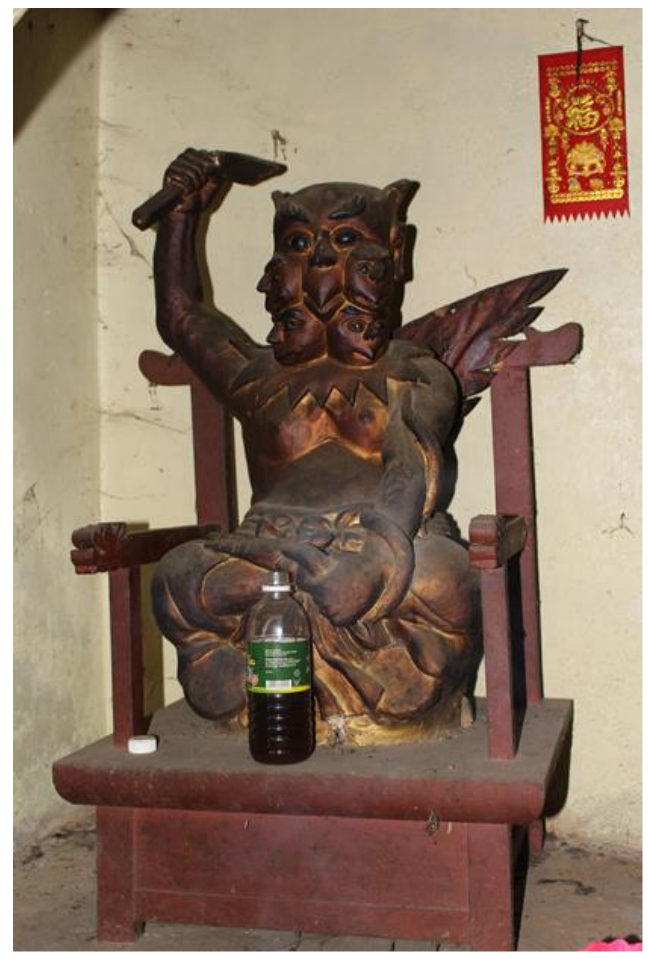

\section{Picture 6: A Bizarre Deity Statute In Nam Thean Tong}

The Hokkien dialect folk adage said: “The brother pig's nose, the Mr Thunder's beak (猪哥 鼻, 雷公嗀)". The unusual stature should be the Thunder gods. Its identification is not only based on its beak but also on the instrument grasped on its right hand. The instrument is similar to a thunder hammer. Therefore, it can be concluded that the odd statue is the Thunder God. Since then, this type of stature has only been found in Nam Theam Tong.

\section{Awaking Poem}

The awakening poems in Nam Thean Tong were written by a Taoist priest, Gong Shan De (龔 善德, 1870--?). The awakening poem consists of 39 poems, written under the mural. The first poem, which was written in 1905 demonstrated the origin of the poem series:

Last mid-night, I woke up startled and awoke this was only a dream.

After awaking, I felt that being enlightened.

Hence I wrote the Taoist sentiment on the wall

To savage of devout men and women.

The poem is mainly describing the process and pursuing of Taoism self-cultivation. He mentioned the charm of fame and fortune, the greedy nature of human beings, and the impermanent world. The poem advised people to seek their inner consciousness and to follow the path of Tao. Although Gong Shan De was a Taoist priest, his awakening poem had used Copyright $\odot$ GLOBAL ACADEMIC EXCELLENCE (M) SDN BHD - All rights reserved 
Volume 4 Issue 15 (December 2021) PP. 14-32 DOI 10.35631/IJHAM.415002

many Buddhist terms and concepts. For instance, the term sarira, bodhi, four forms of life and six realms of existence. He also stated, "Took the refugee to Buddha is not the conflicting (with Taoism)".

The poem series reveals the hybridisation of Taoism and Buddhist during that period. Regrettably, about $10 \%$ of the character went unrecognised. Nonetheless, these poem series are among the precious Chinese literature arts. Compared with Buddhist intelligentsia monks who wrote a lot of awakening poems, the awakening poem left by a Taoist priest is very rare. This series of awaking poems, written over a century ago, is valuable for further research.

\section{Cave Temples' Historical Materials Before World War II}

Historical evidence is essential for the construction of history. The study of cave temples in Perak relies on two types of primary sources. First, British official records - Perak Government Gazette (1895-1906) and second, the epigraphical materials.

\section{Official Records}

Table 3 shows the cave temples that were registered after the Societies Act 1895. From the compiles of the Perak Government Gazette from 1895 to 1909, there are eight Chinese Cave temples. Kwong Seng Ngam and Fuk Shan Ngam disappeared already. Nam Lung Ku Miu is set to disappear. Today, the site of Nam Lung Ku Miu has become Thrangu Dhamma Retreat Centre. Kwong Seng Ngam left the cave and relocated to New Village.

\begin{tabular}{|c|c|c|c|c|}
\hline \multirow[t]{2}{*}{ Year } & \multicolumn{2}{|l|}{ Cave Temple } & \multirow[t]{2}{*}{ Location } & \multirow[t]{2}{*}{ Note } \\
\hline & $\begin{array}{l}\text { Registered } \\
\text { Name }\end{array}$ & Chinese Name & & \\
\hline \multirow[t]{6}{*}{1895} & Nam To Ngam & 南道岩 & Cave in Ipoh & \\
\hline & $\begin{array}{l}\text { Nam Lung } \mathrm{Ku} \\
\text { Miu }\end{array}$ & 南龍古廟 & $\begin{array}{l}\text { In a Cave at } \\
\text { Tanjong } \\
\text { Rambutan }\end{array}$ & $\begin{array}{l}\text { Now: Thrangu } \\
\text { Dhamma Retreat } \\
\text { Centre }\end{array}$ \\
\hline & Wan Sin Tung & 雲仙洞 & $\begin{array}{l}\text { Kampong } \\
\text { Kepayang, } \\
\text { Sungei Raia } \\
\end{array}$ & Abandoned \\
\hline & $\begin{array}{ll}\text { Kwong } & \text { Fuk } \\
\text { Ngam } & \\
\end{array}$ & 廣福岩 & Do. Do & \\
\hline & Fuk Shan Ngam & 福山岩 (?) $)^{\mathrm{ii}}$ & Polai & Disappear \\
\hline & $\begin{array}{ll}\text { Kwong } & \text { Seng } \\
\text { Ngam } & \\
\end{array}$ & 廣聖岩 & Do. & $\begin{array}{l}\text { Move to New } \\
\text { Village in Ipoh }\end{array}$ \\
\hline 1897 & Nam To Yin & 南道院 & & \\
\hline 1906 & $\begin{array}{ll}\text { Lung } & \text { Thau } \\
\text { Ngam } & \\
\end{array}$ & 龍頭岩 & & \\
\hline
\end{tabular}

Table 3: Registered Cave Temples in Ipoh (1895-1909) ${ }^{\text {iii }}$

Similar to other societies in Malaya, some cave temples did not register to the government. The epigraphical materials have manifested their existence. 


\section{Epigraphical Materials}

The definition of epigraphic material in this paper is "the script incised on stone, metal, tin, wooden or other solid materials." There are different types of epigraphic materials in the cave temple, such as:

A: Musical Instruments such as a bronze bell. The artefact is usually made in bronze.

B: Religious Majestic symbols consist of the land and ceremonial boards, or better known as the board of Zhishi (執事牌)

C: Stone or Wooden tablet, in rectangular or in pairs.

D: Table, or gods' table.

\begin{tabular}{|c|c|c|c|c|c|c|}
\hline Temple & Type & Artefacts & Year & Content & Donated & Remark \\
\hline \multirow{5}{*}{$\begin{array}{l}\text { Kwong } \\
\text { Fook } \\
\text { Ngam }\end{array}$} & A & $\begin{array}{l}\text { Bronze } \\
\text { Bell }\end{array}$ & 1895 & & $\begin{array}{l}\text { Rev. Wei } \\
\text { Jia (微嘉) }\end{array}$ & \\
\hline & $\mathrm{C}$ & $\begin{array}{l}\text { Wooden } \\
\text { Tablet }\end{array}$ & 1907 & $\begin{array}{l}\text { Climb the cave to } \\
\text { respect the appearance } \\
\text { (登岩禮相) }\end{array}$ & $\begin{array}{l}\text { Rev. Wei } \\
\text { Jia }\end{array}$ & \\
\hline & B & $\begin{array}{l}\text { Board of } \\
\text { Zhishi }\end{array}$ & 1907 & $\begin{array}{l}\text { Solemn Silence( 肅 靜) } \\
\text { To Duck (迴避) } \\
\text { Kwong Fok Ngam (廣福 } \\
\text { 岩) } \\
\text { Guan Yin Buddha (觀音 } \\
\text { 佛祖) }\end{array}$ & $\begin{array}{l}\text { Fujian } \\
\text { Tongan } \\
\text { Zhou Shui } \\
\text { Yun () }\end{array}$ & $\begin{array}{l}\text { Four } \\
\text { wooden } \\
\text { plaque }\end{array}$ \\
\hline & B & $\begin{array}{l}\text { The lance } \\
\text { and } \\
\text { ceremonial } \\
\text { boards }\end{array}$ & 1903 & & $\begin{array}{l}\text { Fujian } \\
\text { Tongan } \\
\text { Zhou Shui } \\
\text { Yun (周 水 } \\
\text { 蘊) }\end{array}$ & $\begin{array}{l}\text { Four } \\
\text { symbol } \\
\text { items: axe, } \\
\text { hammer, } \\
\text { pen and } \\
\text { dragon. }\end{array}$ \\
\hline & $\mathrm{C}$ & $\begin{array}{l}\text { Wooden } \\
\text { tablet }\end{array}$ & 1908 & $\begin{array}{l}\text { Record the history of the } \\
\text { temple, which originated } \\
\text { in } 1890 \text {. }\end{array}$ & & \\
\hline \multirow[t]{3}{*}{$\begin{array}{l}\text { Nam Tou } \\
\text { Ngan }\end{array}$} & A & $\begin{array}{l}\text { Bronze } \\
\text { Bell }\end{array}$ & 1893 & $\begin{array}{l}\text { Timely Wind and Rain } \\
\text { (風調兩順) }\end{array}$ & $\begin{array}{l}\text { Merchant } \\
\text { of Paloh }\end{array}$ & \\
\hline & $\mathrm{C}$ & $\begin{array}{l}\text { Wooden } \\
\text { tablet in } \\
\text { pair }\end{array}$ & 1895 & $\begin{array}{l}\text { Describe the beauty of } \\
\text { the cave temple, Sakya } \\
\text { deliver being. }\end{array}$ & $\begin{array}{l}\text { Founder of } \\
\text { the Taoist } \\
\text { priest }\end{array}$ & \\
\hline & $\mathrm{C}$ & $\begin{array}{l}\text { Wooden } \\
\text { tablet in } \\
\text { pair }\end{array}$ & 1895 & $\begin{array}{l}\text { Appreciate the secret of } \\
500 \text { words (Daode Jing) }\end{array}$ & $\begin{array}{l}\text { Zhang } \text { Qi } \\
\mathrm{Li} \text { (張 啓 } \\
\text { 立 ) from }\end{array}$ & \\
\hline
\end{tabular}


Volume 4 Issue 15 (December 2021) PP. 14-32 DOI 10.35631/IJHAM.415002

\begin{tabular}{|c|c|c|c|c|c|c|}
\hline & & & & & $\begin{array}{l}\text { Guishan } \\
\text { (歸善) }\end{array}$ & \\
\hline & $\mathrm{D}$ & $\begin{array}{l}\text { Worship } \\
\text { Table }\end{array}$ & 1901 & $\begin{array}{l}\text { The Supreme Elderly } \\
\text { Lord and Buddha }\end{array}$ & $\begin{array}{l}\mathrm{Gu} \quad \mathrm{Wu} \\
\text { Xin（啈務 } \\
\text { 心） }\end{array}$ & \\
\hline & $\mathrm{C}$ & $\begin{array}{l}\text { Wooden } \\
\text { Tablet }\end{array}$ & 1907 & Nam Tou Ngam & $\begin{array}{l}\mathrm{Gu} \quad \mathrm{Wu} \\
\text { Xin }\end{array}$ & \\
\hline & $\mathrm{C}$ & $\begin{array}{l}\text { Wooden } \\
\text { Tablet }\end{array}$ & 1909 & $\begin{array}{l}\text { Jade Teacher Temple } \\
\text { (玉觀堂) }\end{array}$ & $\begin{array}{l}\text { Dai Wei } \\
\text { An (戴威 } \\
\text { 安) }\end{array}$ & \\
\hline & $\mathrm{D}$ & $\begin{array}{l}\text { Worship } \\
\text { Table }\end{array}$ & 1909 & & & \\
\hline \multirow{3}{*}{$\begin{array}{l}\text { Loong } \\
\text { Thow } \\
\text { Ngam }\end{array}$} & $\mathrm{A}$ & $\begin{array}{l}\text { Bronze } \\
\text { Bell }\end{array}$ & 1911 & Timely Rain and Wind & & \\
\hline & $\mathrm{C}$ & $\begin{array}{l}\text { Wooden } \\
\text { Tablet }\end{array}$ & 1914 & & $\begin{array}{l}\text { A group of } \\
\text { devotees }\end{array}$ & \\
\hline & $\mathrm{C}$ & $\begin{array}{l}\text { Stone } \\
\text { Tablet }\end{array}$ & 1919 & $\begin{array}{l}\text { Record the history of the } \\
\text { temple which began in } \\
1895\end{array}$ & & \\
\hline $\begin{array}{l}\text { Nam } \\
\text { Thean } \\
\text { Tong }\end{array}$ & A & $\begin{array}{l}\text { Bronze } \\
\text { Bell }\end{array}$ & 1899 & Timely Rain and Wind & $\begin{array}{l}\text { Chen Xi } \\
\text { Sheng (陳 } \\
\text { 喜盛) }\end{array}$ & \\
\hline \multirow{2}{*}{$\begin{array}{l}\text { Tung } \\
\text { Wah } \\
\text { Tong }\end{array}$} & A & $\begin{array}{l}\text { Bronze } \\
\text { Bell }\end{array}$ & 1916 & Timely Rain and Wind & & \\
\hline & $\mathrm{C}$ & $\begin{array}{l}\text { Wooden } \\
\text { Tablet }\end{array}$ & 1936 & $\begin{array}{l}\text { The Heaven of } \\
\text { Immortals (玄圃閬風) }\end{array}$ & $\begin{array}{l}\text { Leong Sin } \\
\text { Nam and } \\
\text { others }\end{array}$ & \\
\hline \multirow[t]{2}{*}{$\begin{array}{l}\text { Sam Poh } \\
\text { Tong }\end{array}$} & $\mathrm{A}$ & $\begin{array}{l}\text { Bronze } \\
\text { Bell }\end{array}$ & 1931 & $\begin{array}{l}\text { The bell will enlighten } \\
\text { the being. }\end{array}$ & $\begin{array}{l}\text { The abbot } \\
\text { Ming } \\
\text { Miao ( 明 } \\
\text { 妙 ) and } \\
\text { others. }\end{array}$ & \\
\hline & $\mathrm{C}$ & $\begin{array}{l}\text { Wooden } \\
\text { Tablet }\end{array}$ & 1936 & $\begin{array}{l}\text { Tushiha Heaven（兜率 } \\
\text { 宮） }\end{array}$ & & \\
\hline \multirow[t]{2}{*}{$\begin{array}{l}\text { Kwong } \\
\text { Seng } \\
\text { Ngan }\end{array}$} & $\mathrm{C}$ & $\begin{array}{l}\text { Wooden } \\
\text { Tablet }\end{array}$ & 1901 & $\begin{array}{l}\text { List of the temple rebuilt } \\
\text { donors }\end{array}$ & $\begin{array}{l}\text { Foo Choo } \\
\text { Choon and } \\
\text { others }\end{array}$ & \\
\hline & $\mathrm{A}$ & $\begin{array}{l}\text { Bronze } \\
\text { Bell }\end{array}$ & 1910 & $\begin{array}{l}\text { Kwong Seng Ngan of } \\
\text { Pulai }\end{array}$ & & Broker \\
\hline
\end{tabular}

Table 4: Epigraphic Materials of The Cave Temples Before World War Two

Table 4 shows the artefacts with epigraphic inscriptions discovered in loci at these cave temples. The bronze bell is the most common artefact in the temple. The musical instrument is usually played in religious ceremonies, such as morning and evening chanting in Buddhist temples, 
Volume 4 Issue 15 (December 2021) PP. 14-32 DOI 10.35631/IJHAM.415002

which is coordinated with a drum. Kwong Fook Ngam is likely to be the oldest limestone cave temple in Ipoh.

Besides these epigraphic materials, these temples contain some paper materials. For instance, the Dudie (度牒), or the Degree of Taoism, dated 1922. The Dudie was kept in Loong Thow Ngam, the only local lineage of Malaysia's Quanzhen School. Perak Tong, a famous tourist resort in Ipoh did not preserve any historical relic before world war II. Nonetheless, the painting of Perak Tong by Zhong Bai Mu (鍾白木) in 1941 is considered as the earliest evidence that the temple was constructed before world war II.

\section{Conclusion}

This is empirical research to determine the number of cave temples in Ipoh. Today, 50 cave temples can be traced. The paper divided "cave temple" into three types: Cave temple (39); a temple in the cave's vicinity (10); an abandoned cave temple (1). Among these temples, 9 of them (Kwong Fook Ngam, Nam Tou Ngam, Loong Thow Ngam, Nam Thean Tong, Tung Wah Tong, Sam Poh Tong, Perak Tong, Kwong Seng Ngan and Wan Sin Tong) proved to be established before the World War II. The abundance of cave temples reveals Malaysia's religious freedom.

The visual and literary arts discussed in this paper are focused on the arts and historical remains kept at Nam Thean Tong, a Taoist Cave temple. The old temple records more than 300 deity names. In other words, most deities are worshipped in this temple in Malaysia. The temple is similar to the Chinese Taoism Arts Museum in Malaysia. The painting, which includes pictures of deities, and a mural depicting ancient Chinese legends, the Hakka style antique statute, and the awaking poem, was only captured in this temple. The arts continue to be discovered in Nam Thean Tong trend as an inheritance from China with no localised elements found.

Compared to Wolfgang Franke and Chen Tieh Fan's collection, epigraphic materials of more than seven folds were discovered in the temples in Kinta District. Wolfgang and Chen did not collect even one epigraphical material in these cave temples. The world has most likely forgotten about the historical relics that have been lying for hundreds of years. The research team even found a hundred-year-old historical relic in the dark and humid storeroom. The paper attempts to go a further step from the book Trails of the Nanyang Chinese: History and Legends of the Cave Temple in Ipoh of Malaysia, by not only summarising the work but also embedding the new findings until January 2020.

This is the research that is racing with time. These cave temples may have been well-known during British colonial periods. Today, the old photos can be found in Malaysia National Archives. The wonderful photo not only reveals the old features of these cave temples but also historical relics during that time. For instance, an old photo of Nam Tou Yan shows three wooden tablets, but they have disappeared now. The hot and humid weather damaged the historical relic. The Religious Majestic Symbols of Kwong Fook Ngam are in bad condition. Research work such as collecting epigraphic materials is valuable, not only for research purposes but also to raise awareness about the importance of these materials in our search of the past, which can bring explanation and understanding to the present. 
Volume 4 Issue 15 (December 2021) PP. 14-32 DOI 10.35631/IJHAM.415002

The inheritance may be an imminent challenge for these cave temples, especially those established before World War II. During the years that these temples were discovered, the Buddhist temples were managed by the Buddhist monk, and the Taoism temples were controlled by a Taoist priest. Time flies and the religious teacher could not find their apprentice. Most cave temples that were established before World War II are no longer managed directly by religious authorities, except Sam Poh Tung and Lung Tou Ngam. Whatever researchers can do is record the contemporary findings, before they get destroyed or disappeared.

\section{Reference}

Federated Malay State Government (1895 -1909), Federated Malay State Government Gazette. Malaya: Author.

Foo Yen Chew (ed) (2014). Important Tombs: Epigraphy Documents of Kwong Tong Cemetery Kuala Lumpur, Kuala Lumpur: Centre for Malaysia Chinese Studies. 古燕 秋(編著)(2014)。《死生契闊 : 吉隆坡廣東義山墓碑與圖文輯要》。吉隆坡 : 華 社研究中心。

Hare, G. T. (1902). Federated Malay States : census of the population, 1901 , Kuala Lumpur : Government Printer.

Ling Liong Ngo (2017). The Study of a classical poetry in Cave Temple in Malaysia - The discussion of Perak Tung Eight Views Poetry Anthology. Paper presented at The 9th International Conference of Classical Writing of China , 12 to 14 November, Guangdong, China. 林良娥(2017)。馬來西亞嚴洞廟宇的舊體詩研究——以《霹 靂洞八景詩集》為探討對象，發表於第九屆中國韻文學國際學術研討會，中國 韻 文學會和暨南大學文學院聯合主辦，中國廣州裕通大酒店。

Liow Min Wei (2017), Nam Theam Tong. In Tan Ai Boay and Toh Teong Chuan (Eds). Trails of the Nanyang Chinese: History and Legends of the Cave Temples in Ipoh of Malaysia (pp. 111-162). Beijing: China Social Science Press. 廖明威（2017）。〈南天洞一百 年首觀的遺跡和傳奇〉（第 111--162 頁）。收錄在陳愛梅、杜忠全(主編), 《南 洋華蹤：馬來西亞霹靂怡保嚴洞廟宇史錄與傳說》，北京：中國社會科學出版社。

Lew Bon Hoi and Chong Kok Ming (2016). Sino-Malay Goodwill Assessed : The Case of Kampung Baru Machap, Melaka', Overseas Chinese Journal of Bagui (2), 40—44. 廖 文輝 莊國民 (2016), 〈試析馬來西亞華巫親善之事例——以馬六甲馬接新村為 例〉，《八 桂 僑 刊》，第 2 期，第 40-44 頁。

Perak Government (1889), Perak Government Gazette 1889. Perak: Author

Pountney, A. M (1911). The Census of the Federated Malay States, 1911. Review of the Census Operations and Results Including Tables Exhibiting the Population by Sex, Age, Race, Birthplace, Religion and Occupation, London: Darling.

Tan Ai Boay (2015). Who is the Buddhist? The Preliminary Study of Buddhist Faith among the Malaysian Chinese. The World Religious Cultures (2,). 70-76. 陳愛梅(2017)。

〈誰是佛教徒? 佛教徒是誰? 馬來西亞佛教信仰探析〉 《世界宗教文化》，第 2 期, 第 70 至 76 頁。

Tan Ai Boay (2017). The Relationship between Hoklo and Hakka in Malaysia: A Study of Tombstones in Gertak Sanggul and Tanjong Asam Chinese Cemeteries in Penang, Global Hakka Studies (9), 183-206. 陳愛梅， 2017), 〈馬來西亞福佬人和客家人 
Volume 4 Issue 15 (December 2021) PP. 14-32 DOI 10.35631/IJHAM.415002 的關系探析：以檳城美湖水長華人義山墓碑為考察中心》《全球客家研究》， 第 9 期, 第 183-206 頁。

Tan Ai Boay and Toh Teong Chuan (eds) (2017). Trails of the Nanyang Chinese: History and Legends of the Cave Temples in Ipoh of Malaysia. Beijing: China Social Science Press. 陳愛梅、杜忠全(主編)(2017), 《南洋華蹤：馬來西亞霹震怡保巖洞廟宇史錄與 傳說》，北京：中國社會科學出版社。

Toh Teong Chuan (2017). A Taoist priest awakening poem in Nam Thean Thung, Ipoh. Paper presented at the 6th International Conference on South East Asia Religions. 28th October. Gansu, China. 杜忠全, 〈怡保南天洞的道士醒世詩〉，發表於第六屆東 南亞宗教研究高端論壇, 中 國社會科學院世界宗教研究所暨西北民族大學等聯 合主辦, 甘肅臨夏。

Vlieland, C. A (1932). British Malaya (the Colony of the Straits Settlements and the Malaya States under British protection, namely the federated states of Perak, Selangor, Negri Sembilan and Pahang and the states of johore, Kedah, Kelantan, Treangganu, Perlis and Brunei), London : Crown Agents for the Colonies.

Wang, Tze Ken Danny (2016). Early Chinese Presence in Malaysia as Reflected by three Cemeteries (17th-19th c.), Archipel 92, p. 9-21.

Wolfgang Franke and Chen Tieh Fan (eds) (1982, 1985 and 1987). Chinese Epigraphic Materials in Malaysia , Kuala Lumpur: University Malaya Press.

Wong Wun Bin (2013). A Collection of Tombstone Inscription of Bukit China, Malacca (16141820). Kuala Lumpur: Centre for Malaysian Chinese Studies. 黃文斌 (2013)《馬六 甲三寶山墓碑集錄》（1614-1820）。吉隆坡：華社研究中心。

\footnotetext{
${ }^{i}$ Tan Chaw Hui and Liow Min Wei, fresh graduate worked as the Research Assistance under the research project led by Dr. Tan Ai Boay, assisted by her colleague Toh Teong Chuan. The first batch of research assistance carried out the most challenge and tough research works. They drove along the limestone hill in Ipoh to find out the cave temples. Later, Ong Min Yu, Amy Ling Su Ping and Tang Man Hong joined the research team.

ii The government gazette did not record the Chinese name. The temple disappeared now. The Chinese name only based on the dialect pronunciation.

iii Compiles from Federated Malay States Government Gazette 1895 to 1909.
} 